\title{
AS ORIGENS EVOLUTIVAS DA COOPERAÇÃO HUMANA E SUAS IMPLICAÇÕES PARA A TEORIA DO DIREITO
}

\author{
Fábio Portela Lopes de Almeida \\ THE EVOLUTIONARY ORIGINS OF HUMAN COOPERATION \\ AND ITS IMPLICATIONS FOR LEGAL THEORY
}

\section{RESUMO}

A TEORIA DARWINISTA TEM CONTRIBUÍDO PARA A DISCUSSÃO DE PROBLEMAS NOS MAIS DIVERSOS CAMPOS FILOSÓFICOS, ENTRE OS QUAIS SE INCLUI A ÉTICA E A TEORIA MORAL. TENDO EM VISTA QUE AS CIÊNCIAS SOCIAIS TÊM REJEITADO TENTATIVAS BIOLÓGICAS DE EXPLICAR O COMPORTAMENTO NORMATIVO HUMANO, A PRIMEIRA SEÇÃO SERÁ DESTINADA A MOSTRAR OS MOTIVOS DESSA REJEICÃO E COMO A TEORIA DA DUPLA HERANÇA OS SUPERA. SEUS PRESSUPOSTOS SÃO EXPLICITADOS NA SEGUNDA SEÇÃO. AO ASSUMIR QUE A CULTURA É UMA CAUSA ÚlTIMA DA EVOLUÇÃO HUMANA, A TEORIA DA DUPLA HERANCA SUPERA DIFICULDADES ENCONTRADAS POR OUTRAS ABORDAGENS EVOLUTIVAS QUE PRETENDERAM EXPLICAR A EVOLUCC̃O DO COMPORTAMENTO NORMATIVO HUMANO, AO SALIENTAR A EVOLUÇÃO DA PSICOLOGIA SOCIAL HUMANA E DOS INSTINTOS RESPONSÁVEIS PELO RACIOCÍNIO MORAL E JURÍDICO. NESTA PERSPECTIVA, RECONHECE-SE QUE HÁ PRINCÍPIOS MORAIS INATOS E UNIVERSAIS INCORPORADOS A MENTE HUMANA, QUE IMPOSSIBILITAM A ESTABILIZAÇÃO CULTURAL DE NORMAS MORAIS/JURÍDICAS INCOMPATÍVEIS COM ELES. ESSA TESE É DEBATIDA NA ÚLTIMA SEÇÃO DO ARTIGO, NA QUAL SE DISCUTE A PROBLEMÁTICA RELAÇÃO ENTRE DIREITO NATURAL E POSITIVO, UM PROBLEMA CLÁSSICO DA TEORIA MORAL E JURÍDICA.

\section{PALAVRAS-CHAVE}

Dupla herança; EVOLUÇão da COOPERAÇÃo; FILOSOFIA MORAL; JUSNATURALISMO, DARWINISMO.

\section{ABSTRACT}

A DARWINIAN EVOLUTIONARY APPROACH CAN CONTRIBUTE TO EVALUATE PHILOSOPHICAL PROBLEMS IN DIFFERENT FIELDS, INCLUDING ETHICS AND MORAL THEORY. SINCE SOCIAL THEORY HAS REJECTED BIOLOGICAL ATTEMPTS TO EXPLAIN HUMAN BEHAVIOR, THE FIRST SECTION OF THE ARTICLE AIMS TO DISCUSS THE REASONS OF THIS REJECTION AND TO SHOW HOW NEW THEORIES, LIKE DUAL INHERITANCE THEORY, HAVE BEEN ABLE TO OVERCOME THEM. THE ASSUMPTIONS OF DUAL INHERITANCE THEORY ARE DEBATED IN SECTION 2. ASSUMING THAT CULTURE NOT ONLY IS THE OUTCOME FROM GENETIC EVOLUTION, BUT ALSO AN IMPORTANT FORCE IN HUMAN EVOLUTIONARY HISTORY, DUAL INHERITANCE THEORY ADDRESSES HUMAN COOPERATION AND THE UNDERLYING PSYCHOLOGICAL MECHANISMS IN A DISTINCTIVE WAY. IN CONTRAST WITH OTHER BIOLOGICAL THEORIES THAT INTENDED TO EXPLAIN HUMAN NORMATIVE BEHAVIOR, DUAL INHERITANCE THEORY INNOVATES BY TAKING INTO ACCOUNT THE EVOLUTION OF HUMAN SOCIAL PSYCHOLOGY AND OF THE INSTINCTS RESPONSIBLE FOR MORAL REASONING. IN THIS SENSE, IT RECOGNIZES THAT THERE ARE INNATE MORAL PRINCIPLES NESTED IN HUMAN MIND THAT MAKES IMPOSSIBLE THE CULTURAL STABILIZATION OF MORAL/LEGAL NORMS THAT TURN OUT TO BE INCOMPATIBLE WITH THEM. THIS HYPOTHESIS IS DISCUSSED IN THE THIRD SECTION, WHICH DEPLOYS FURTHER THIS NATURALISTIC STANDPOINT BY APPLYING DUAL HERITANCE THEORY TO THE SO-CALLED 'NATURAL RIGHT' ISSUE, A CLASSICAL PROBLEM FOR MORAL AND LAW.

\section{KEYWORDS}

DUAL INHERITANCE; EVOLUTION OF COOPERATION; MORAL PHILOSOPHY; JUS NATURALISM: DARWINISM. 


\section{INTRODUÇÃO}

O comportamento social humano é uma anomalia na natureza. Ao contrário dos outros animais, o Homo sapiens vive em sociedades compostas de milhões de indivíduos capazes de se organizar por meio de instituições e de normas sociais que coordenam sua vida em comum. Talvez os insetos sociais (como abelhas, formigas e cupins) constituam o exemplo natural mais próximo da complexidade da vida social humana. Mas é inegável que a vida social das abelhas é bastante menos complexa do que os meandros da sociabilidade da espécie humana. E mesmo espécies mais próximas da humana, como a dos chimpanzés, que também vivem em sociedades compostas de dezenas de indivíduos, mas muito menores do que as humanas, não apresentam em sua vida social a complexidade da nossa.

O Homo sapiens vive em sociedades reguladas por normas e instituições sociais (como o direito, a moral e a religião, entre tantas outras), e isso é tão natural em nossa espécie que mesmo crianças pequenas são capazes de raciocinar normativamente (HAUSER, 2006, p. 21). E essa aparente anomalia presente no mundo natural apresenta um problema para os biólogos evolucionistas: como explicar o surgimento de uma espécie capaz de viver de acordo com normas sociais institucionalizadas?

O primeiro objetivo deste artigo é traçar uma possibilidade de resposta a esta pergunta à luz de uma abordagem teórica desenvolvida desde o início da década de 1980: a teoria da dupla herança. Trata-se de um marco teórico que busca explicar a evolução do comportamento social humano a partir de premissas extraídas tanto das ciências sociais quanto das ciências biológicas, concedendo à cultura um papel fundamental na evolução da espécie humana. Essa proposta possibilita lançar um novo olhar sobre o comportamento normativo humano e para a teoria do direito. Para ilustrar as possibilidades de aplicação da teoria da dupla herança à teoria jurídica, o artigo examinará um problema que foi central para a teoria do direito por muitos séculos, apesar de ter sido relativamente abandonada nas últimas décadas: a possibilidade concreta do direito natural e a sua relação com o direito positivo.

A primeira seção se destinará a abordar a relação entre as ciências sociais e a biologia. Essa discussão, apesar de aparentemente desvinculada da proposta central do artigo, justifica-se em razão de ser fundamental para que se compreenda como a teoria da dupla herança se diferencia das abordagens biológicas tradicionais e, além disso, não incorre nos problemas teóricos que levaram à rejeição dos modelos biológicos como possível fonte de explicação do comportamento social humano.

A seção seguinte se destinará a explicitar os pressupostos da teoria da dupla herança, com o objetivo de ressaltar os principais conceitos adotados e as diferenças entre esse marco teórico e outras teorias biológicas que pretenderam explicar o comportamento humano. Esta seção também abordará como a teoria da dupla herança possibilita explicar a evolução da mente normativa, ou seja, a capacidade intelectual de realizar a cognição de normas morais/jurídicas. Trata-se de questão central para a proposta do 
artigo, já que explicita a função da psicologia humana na sustentação das instituições que caracterizam nossa sociabilidade.

Por fim, na última seção, será discutida a questão central do artigo: a possibilidade de defender o direito natural como uma decorrência da psicologia social humana, que é produto do panorama evolutivo proposto pela teoria da dupla herança. As teorias jusnaturalistas estruturam a validade do direito invocando a tese de que existem princípios normativos universais, cuja validade não deriva de normas socialmente estabelecidas, mas da própria natureza. Segundo essa abordagem, a validade do direito positivo deriva do direito natural. Essa tese pode ser defendida a partir de uma abordagem que valorize as contribuições da biologia, que notoriamente valoriza os aspectos universais do comportamento humano, sem desconsiderar a diversidade humana, que é explicitada pelas ciências sociais?

\section{A REJEIÇÃo do DARWinismo PELA TEORIA SOCIAL}

A teoria social tem rejeitado, nas últimas décadas, as abordagens teóricas que pretendam explicar o comportamento humano a partir da biologia. Foram várias as razões para que isso ocorresse. Entre elas, destaca-se a circunstância de que muitas das teorias biológicas não atribuem à cultura um papel relevante para explicar o comportamento humano. Isso se deve à ênfase que esses cientistas costumam atribuir à continuidade entre o comportamento de seres humanos e de outros animais. A evolução biológica é um processo gradual, que não admite saltos (DENNETT, 1998, p. 301-304). As enormes diferenças entre uma espécie e outra são construídas ao longo de milhares de gerações, fruto da atuação lenta e persistente do processo de seleção natural. Por essa razão, muitos biólogos e etólogos esperam poder explicar o comportamento humano a partir de características que compartilhamos com outros animais. Nessa perspectiva, o apelo à cultura como uma explicação para os comportamentos humanos parece supor que há uma cisão irreconciliável entre a espécie humana e todo o restante do mundo animal, o que violaria a premissa do gradualismo. ${ }^{1}$

Segundo os cientistas sociais, no entanto, nosso comportamento apresenta diversidade inigualável em relação a outras espécies animais porque não depende somente de nossa psicologia, mas também das normas e das instituições que compõem a cultura de uma sociedade. ${ }^{2}$ Émile Durkheim, um dos pais da sociologia moderna, defendia a tese de que o estudo da sociedade independe do estudo da psicologia individual, uma vez que a natureza do indivíduo que é afetada e moldada pela cultura, não o contrário (DURKHEIM, 2006, p. 113-117). Trata-se de premissa inerente ao pensamento antropológico e sociológico, como salienta Roberto DaMatta (1993, p. 44-45).

Há, ainda, outra razão para os cientistas sociais rejeitarem a biologia: as implicações políticas dos primeiros empreendimentos científicos que buscaram explicar a 
sociabilidade humana a partir da biologia, e ficaram conhecidos sob o título de darwinismo social. Esse movimento político e teórico foi influenciado por uma leitura equivocada de Darwin, baseado em duas premissas distintas: a eugenia e a ideia de que a evolução biológica implicava, necessariamente, progresso (PINKER, 2004, p. 44-45). Mas essas implicações políticas não são uma decorrência necessária da teoria darwinista (LALAND; BROWN, 2002). A rigor, é difícil enxergar o darwinismo social, a ideia de evolução como progresso ou o movimento eugênico nazista como resultados diretos da teoria de Darwin, que rejeitou explicitamente a eugenia e tampouco era favorável à tese da superioridade de uma raça sobre outra (LALAND; BROWN, 2002). Darwin também rejeitava expressamente a tese de que a evolução tem uma direção predeterminada.

Além disso, embora o darwinismo social e a sociobiologia tenham sido utilizados para justificar posições políticas conservadoras, essa não é uma implicação necessária da teoria darwinista. Afinal, uma abordagem darwinista que pretenda explicar toda a diversidade do comportamento moral humano precisa considerar a enorme abrangência de atitudes morais e políticas percebidas em nossa espécie. Somos capazes de adotar inúmeras posições políticas, alinháveis à direita e à esquerda, e a teoria darwinista pode, no máximo, explicar por que temos uma mente capaz de adotar esse espectro de posições. Justificar uma determinada visão política com base na teoria darwinista seria abusar de suas possibilidades explicativas.

Novos programas de pesquisa desenvolvidos nos últimos trinta anos têm reconhecido a necessidade de aproximar a biologia das ciências sociais, incorporando a premissa de que a cultura é, tal como defendido pela sociologia e pela antropologia, uma causa importante do comportamento humano.

Entre esses programas, destacam-se as chamadas teorias da coevolução gene-cultura e, em especial, a "teoria da dupla herança”, que será apresentada na segunda seção do artigo e servirá de base para a discussão proposta na segunda parte. Esta abordagem inovou no embate entre biologia e ciências sociais ao propor a tese de que tanto a cultura depende da genética humana quanto o contrário. Segundo ela, fato de sermos seres culturais somente foi possível porque nosso passado evolutivo favoreceu o surgimento de indivíduos capazes de agir de acordo com elementos culturais, e a circunstância de a cultura existir entre nossos ancestrais exerceu forte pressão seletiva sobre nossa genética. Segundo a teoria da dupla herança, a cultura é causa evolutiva de nosso comportamento. Trata-se de uma abordagem fundamentalmente diferente de outras perspectivas teóricas rejeitadas pela teoria social, como a sociobiologia ou a psicologia evolucionista, que não atribuem à cultura qualquer papel relevante na compreensão de nosso comportamento. 


\title{
2 A biologia EM HARMONiA COM AS CiÊNCIAS SOCIAIS:
}

\author{
A TEORIA DA DUPLA HERANÇA
}

\section{I A CUltura como causa Última do comportamento humano}

Embora as ciências sociais considerem óbvia a afirmação de que a cultura é uma causa do comportamento humano, a teoria da dupla herança parte de um pressuposto mais agudo: a cultura é concebida como causa última do comportamento humano. A expressão "causa última" diz respeito a um conceito bastante peculiar à filosofia da biologia. Causas próximas se referem, tipicamente, aos fatores fisiológicos/psicológicos que causam imediatamente um comportamento; causas últimas, por sua vez, estariam relacionadas a causas evolutivas, ou seja, ao modo como a seleção natural moldou estruturas existentes em um organismo para que ele se comporte da maneira como observamos (RICHERSON; BOYD, 2005, p. 10). Assim, quando um sociólogo diz que a cultura é uma causa do comportamento humano, está se referindo a causas próximas. Mas a cultura é, também, causa última do comportamento humano. De acordo com a tese de Richerson e Boyd, ela é responsável não apenas por guiar o comportamento de indivíduos em harmonia com as normas de um determinado grupo, mas, além disso, foi um fator fundamental no processo de evolução da espécie humana.

Nossos ancestrais eram seres culturais, e essa premissa é fundamental para se explicar como a psicologia humana inata evoluiu. Segundo Peter Richerson (um biólogo) e Robert Boyd (um antropólogo), a evolução humana é diferente da evolução de outras espécies animais por ter sido o resultado do entrelaçamento de dois tipos de herança - a herança genética e a herança cultural.

Essa perspectiva torna a teoria da coevolução gene-cultura fundamentalmente distinta das perspectivas biológicas tradicionais, como o darwinismo social, a sociobiologia e a psicologia evolucionista. Naquelas abordagens, a cultura é apenas fruto de uma psicologia resultante de processos evolutivos ocorridos na linhagem hominídea, ao passo que, para a teoria da dupla herança, a cultura é um dos fatores que levaram à evolução daquela psicologia (RICHERSON; BOYD, 2005, p. 195).

\subsection{O PENSAMENTO POPULACIONAL COMO ELEMENTO CENTRAL DO DARWINISMO}

A teoria da dupla herança desconstrói um elemento fundamental do darwinismo. Em vez de dar atenção primordial ao mecanismo da seleção natural - como fazem, por exemplo, os sociobiólogos, Richerson e Boyd consideram que a ideia fundamental do darwinismo é o que Ernst Mayr chamava de "pensamento populacional”.

Antes de Darwin, as espécies eram consideradas essências imutáveis, mas o cientista inglês percebeu que as espécies eram populações de indivíduos que carregavam um pool comum de informação variável que era herdada ao longo do tempo (RICHERSON; BOYD, 2005, p. 5). Nessa perspectiva, a seleção natural é um processo que afeta a 
proporção de cada variante informacional nesse pool comum, na medida em que os indivíduos portadores de determinadas variantes, por serem mais aptos precisamente porque a portam, deixam mais herdeiros. Ao longo do tempo, o pool de informação genética pode se tornar bastante diferente do pool de informação inicial, se tornando possível dizer que a espécie "evoluiu".

O pensamento populacional é central para a teoria da cultura proposta por Richerson e Boyd. Definir cultura é uma tarefa árdua: cada teoria privilegia determinadas características em detrimento de outras, sendo possível delimitar no termo “cultura” elementos muito diferentes entre si. A “cultura” é um termo teórico, que somente assume um significado preciso dentro de uma teoria que a define a partir de outros termos. No contexto da teoria da dupla herança:

A cultura é informação capaz de afetar o comportamento dos indivíduos e que eles adquirem de outros membros de sua espécie a partir do ensino, da imitação, e de outras formas de transmissão social (RICHERSON;

BOYD, 2005, p. 5).

Essa definição parte do pressuposto de que a maior parte das diferenças entre as culturas humanas (variação cultural) é causada pela informação armazenada no cérebro de indivíduos, adquirida por meio de mecanismos de aprendizado social (imitação, ensino) e individual (observação). Um povo é culturalmente diferente de outro porque "populações diferentes exibem variações persistentes na linguagem, nos costumes sociais, nos sistemas morais, nas habilidades práticas, nos objetos e na arte. Estas e todas as outras dimensões da cultura existem porque as pessoas possuem habilidades, crenças e valores diferentes que foram adquiridos socialmente" (RICHERSON; BOYD, 2005, p. 6).

O pensamento populacional também informa o modo pelo qual a teoria da dupla herança se relaciona com a teoria social. Segundo Richerson e Boyd, as teorias sociológicas e antropológicas adotam a premissa de que o estudo das sociedades humanas pode prescindir da biologia: partir da cultura de cada sociedade seria suficiente para compreendê-la. Esse modelo é chamado de "superorganicismo" por Richerson e Boyd. Ainda de acordo com esses autores, essa abordagem é fundamentalmente equivocada porque ignora as conexões entre a cultura e a biologia humana. A cultura é parte da nossa biologia:

O superorganicismo está errado porque ignora as ricas interconexões entre a cultura e outros aspectos de nosso comportamento e anatomia. A cultura é tão parte da biologia humana quanto andar ereto. A cultura leva as pessoas a fazerem muitas coisas esquisitas e maravilhosas. Apesar disso, o equipamento nos cérebros humanos, as glândulas produtoras de hormônios e a natureza 
de nossos corpos têm um papel fundamental no modo pelo qual aprendemos e porque preferimos algumas ideias em detrimento de outras. A cultura é ensinada por professores humanos motivados, adquirida por aprendizes motivados, e armazenada e manipulada em cérebros humanos. A cultura é um produto evolutivo de populações de cérebros humanos, cérebros moldados pela seleção natural para aprender a manipular a cultura (RICHERSON; BOYD, 2005, p. 7).

Nessa perspectiva, a cultura não ocorre fundamentalmente em mentes individuais. Isso não significa dizer que a teoria da dupla herança desconsidere as pesquisas e as teorias sociológicas e antropológicas: pelo contrário, vários elementos da teoria da evolução cultural proposta por eles derivam de pesquisas empíricas realizadas por cientistas sociais. Pensar a cultura a partir de processos que ocorrem em indivíduos possibilita explorar as relações entre os fenômenos culturais e os fundamentos biológicos da psicologia humana.

A compreensão das relações entre cultura e biologia, contudo, depende da resposta a várias questões: por que a cultura evoluiu na linhagem hominídea? Qual a função da cultura? Como se originou um novo sistema de herança, distinto da herança genética?

\subsection{A eVoluÇão da CUltura}

A expressão "evolução da cultura" traz embutidos pelo menos dois sentidos bastante diferentes. O primeiro deles se relaciona à evolução da própria cultura como sistema de herança: diz respeito à sua função biológica e ao modo pelo qual ela evoluiu na linhagem hominídea. O segundo sentido da expressão remete à ideia de que a própria cultura evolui ao longo do tempo (daí se falar em evolução cultural, nesse caso). As variantes culturais presentes em um pool cultural modificam-se pelos mais diversos processos, de forma que as variantes presentes no início do processo se tornam bastante diferentes daquelas percebidas posteriormente. O mundo contemporâneo é muito diferente - culturalmente diferente - do mundo antigo, justamente porque ocorre também a evolução cultural: as crenças, desejos, normas e instituições de hoje são o produto de um lento e gradual processo evolutivo.

Apesar de ser possível distinguir esses dois sentidos da expressão "evolução da cultura”, é necessário reconhecer pelo menos uma relação entre ambos. A cultura é um traço das sociedades humanas que evoluiu justamente porque é uma adaptação no sentido biológico. A cultura tornou nossos ancestrais capazes de resolver os problemas ambientais e sociais com que se deparavam, e a seleção natural manteve variantes culturais que os tornou capazes de viver em mundos culturais. ${ }^{3}$

A evolução dessa capacidade possibilitou o surgimento de uma nova forma de cultura: a acumulação cultural ou de cultura cumulativa. As inovações de uma geração 
podem agregar novas melhorias, desenvolvidas por outra geração, e que podem ser implementadas e transmitidas para outra geração (RICHERSON; BOYD, 2005, p. 42-43). O surgimento da cultura cumulativa significou o aparecimento de um novo sistema de herança. Assim como a transmissão genética é um sistema de herança, no qual os filhos herdam determinados genes de seus pais, a cultura (doravante compreendida como cultura cumulativa) também é um sistema de herança, no qual uma geração herda variantes culturais de sua comunidade. Por se tratar de um sistema de herança análogo ao genético, torna-se possível estudar a cultura como um sistema evolutivo - o que leva ao segundo sentido da expressão "evolução da cultura”, que diz respeito à dinâmica por meio da qual a cultura evolui ao longo do tempo.

\subsection{A evolução cultural}

A abordagem darwinista da teoria da dupla herança tem por objetivo explicar porque certas variantes culturais se disseminam, ao passo que outras diminuem sua participação no conjunto de variantes de uma população - analogamente a como se explicam, geneticamente, as mudanças de frequência dos alelos (RICHERSON; BOYD, 2005, p. 60). Em outras palavras, a teoria da dupla herança propõe que a cultura, assim como os genes, é um sistema de herança que evolui ao longo do tempo.

Assim como ocorre na evolução genética, o surgimento de variantes culturais complexas é explicado como o resultado de um longo processo de acumulação de pequenas e graduais variações, que envolvem indivíduos de várias gerações. Uma das vantagens dessa abordagem, ao tratar a evolução cultural analogamente à evolução genética, é a de explicar a alteração da frequência das variantes culturais a partir do mesmo princípio. Em ambos os sistemas de herança, a mudança de frequência das variantes consideradas se deve à atuação de determinadas forças. Na evolução genética, fatores como seleção, mutação e deriva alteram a distribuição dos alelos de uma população.

Do mesmo modo, os autores propõem que a alteração da frequência das variantes culturais se deve a determinadas forças. Algumas delas, como a seleção, a mutação e a deriva, são análogas à evolução genética; outras, contudo, são forças especificamente culturais. Richerson e Boyd propõem a classificação das forças evolutivas que atuam sobre as variantes culturais em três grupos: a) forças aleatórias; b) forças de tomada de decisão; e c) seleção natural.

As forças aleatórias são análogas às da evolução genética: a mutação e a deriva. As forças de tomada de decisão, por sua vez, se dividem em duas modalidades: a variação guiada e a transmissão enviesada. A variação guiada alude à modificação não aleatória da informação cultural adquirida pelo indivíduo e que é subsequentemente transmitida. Essas mudanças resultam de transformações intencionais das variantes culturais, como a invenção de novas variantes ou a modificação adaptativa das já existentes. A variação guiada difere da mutação cultural porque as alterações na variante cultural não são randômicas (RICHERSON; BOYD, 2005, p. 69). Um indivíduo 
pode, a partir de variantes culturais já existentes, alterá-la conscientemente e ensiná-la a outros membros de sua comunidade.

A transmissão enviesada, por sua vez, ocorre quando as pessoas adotam preferencialmente algumas variantes culturais em detrimento de outras (RICHERSON; BOYD, 2005, p. 68-69). Isso indica que a psicologia humana é afetada por vieses, inatos ou adquiridos culturalmente, que afetam o modo pelo qual a mente assimila as variantes culturais. Os vieses inatos seriam causados por características universais da cognição humana, que tornariam mais favorável o aprendizado e a transmissão de determinadas variantes culturais em detrimento de outras. Os vieses culturalmente adquiridos, por sua vez, também tornariam mais favorável o aprendizado de determinadas variantes. Uma comunidade que valorize muito a lealdade familiar, por exemplo, induziria os mais jovens a adquirir esse valor em detrimento de outros. Entre os vieses inatos, destaca-se o conformista, que favorece o aprendizado de variantes culturais comuns em uma determinada população (RICHERSON; BOYD, 2005, p. 69). ${ }^{4}$

A seleção natural é a última força que atua na evolução cultural, e segue a mesma lógica da seleção natural convencional. A seleção natural que atua sobre variantes culturais pode ser definida como a modificação da composição cultural de uma população, decorrente dos efeitos das variantes culturais em quem as adota (RICHERSON; BOYD, 2005, p. 69). Assim como os genes são selecionados em razão dos efeitos fenotípicos que produzem em seus portadores, as variantes culturais também são selecionadas em razão de seus efeitos nos traços fenotípicos - especialmente o comportamento - dos indivíduos que as adotam. Variantes culturais adaptativas tornariam seus portadores mais propensos a terem seu comportamento e suas variantes culturais imitados por outros indivíduos.

As características específicas da evolução cultural a tornam um processo fundamentalmente diferente da evolução genética - e denotam as diferenças entre a teoria da dupla herança e a sociobiologia. Para os sociobiólogos, a seleção natural atua primordialmente sobre os genes que codificam a psicologia individual, moldando, dessa forma, os vieses envolvidos na aquisição e na transmissão da cultura. Nessa perspectiva, o objeto da seleção natural seriam os genes. Como salientado anteriormente, a sociobiologia sustenta que a seleção natural atua somente no nível genético. As variantes culturais seriam selecionadas apenas indiretamente.

Em outras palavras, para a sociobiologia, a cultura seria dominada pelos genes. Se os sociobiólogos estivessem certos, a seleção natural teria moldado a psicologia humana de maneira a favorecer a aquisição de variantes culturais adaptativas, que aumentassem a aptidão biológica. Todavia, isso não é necessário. Os modelos matemáticos analisados por Richerson e Boyd sugerem que a evolução cultural pode favorecer a aquisição de variantes culturais mal-adaptativas do ponto de vista biológico, em virtude da maneira como a informação cultural é transmitida. 
$\mathrm{Na}$ evolução biológica tradicional, a informação genética é transmitida apenas verticalmente, dos pais para os filhos, o que favorece a transmissão de genes que elevam a aptidão biológica. Na evolução cultural, contudo, isso pode não acontecer, porquanto ela admite outros caminhos de transmissão de informação, além do vertical. Existe a transmissão oblíqua (um indivíduo aprende variantes culturais de outros indivíduos da geração anterior) e a transmissão horizontal (a informação é aprendida de outros indivíduos da mesma geração) (CAVALLI-SFORZA, 1986, p. 851). Assim, em que pese o fato de também haver transmissão vertical da informação, os indivíduos aprendem variantes culturais virtualmente de qualquer outra pessoa (RICHERSON; BOYD, 2005, p. 401). Essa característica torna possível que a evolução cultural seja mal adaptativa, induzindo comportamentos que não fazem sentido a partir de uma perspectiva biológica. Obviamente, a evolução cultural também pode ser adaptativa: um indivíduo pode ser mais imitado justamente porque adota variantes culturais codificadoras de comportamentos adaptativos. O surgimento de variantes culturais mal-adaptativas é um efeito colateral dos benefícios da evolução cultural - que, em termos estatísticos, é adaptativa (RICHERSON; BOYD, 2005, p. 162).

\subsection{A EVOLUÇÃO DA MENTE NORMATIVA}

Compreendido o modo pelo qual a teoria da dupla herança concebe o papel da cultura na evolução humana, torna-se possível voltar para a primeira questão do artigo: como explicar o surgimento de uma espécie capaz de viver segundo normas sociais institucionalizadas? A resposta a esta questão pressupõe que o Homo sapiens possui uma psicologia normativa, produto das pressões evolutivas que estiveram presentes em nosso passado ancestral.

A primeira dessas pressões diz respeito à força da seleção de grupo na evolução humana. A ideia de seleção de grupo foi fruto de um polêmico debate na teoria biológica, que diz respeito a qual é o objeto da seleção natural - genes, indivíduos ou grupos. Após um intenso debate, na década de 1970 formou-se um consenso em torno da tese de que apenas os genes são selecionados no processo evolutivo. Trata-se de uma premissa fundamental, por exemplo, na abordagem da sociobiologia e da psicologia evolucionista, que rejeitam a tese de que grupos inteiros poderiam evoluir como produto da seleção natural (SOBER; WILSON, 1998). A teoria da dupla herança, contudo, atribui um papel central à seleção de grupo na evolução humana. ${ }^{5}$ Segundo essa perspectiva, a dinâmica da evolução cultural, por suas características particulares, possibilitou a satisfação inequívoca das condições necessárias para que a seleção de grupo pudesse ser um fator relevante ao lado da seleção de genes.

Para que a seleção natural possa atuar, é necessária a presença de três condições: herança, variação e competição. Desde que essas condições sejam satisfeitas, a seleção natural pode atuar em qualquer nível - genes, indivíduos ou grupos (DENNETT, 
1998). Para atuar no nível dos grupos, portanto, é necessário que essas condições também sejam satisfeitas. A teoria da dupla herança, a partir de elementos extraídos da teoria social, assume que todos esses elementos estão presentes nas sociedades humanas.

Para que a seleção natural atue no nível do grupo, a variação entre os grupos não precisa ocorrer necessariamente no nível genético. O Homo sapiens estar sujeito a um segundo sistema de herança - a cultura cumulativa - possibilitou que a variação ocorresse nesse plano. As sociedades humanas são culturalmente diferentes entre si, ou seja, o conjunto de variantes culturais adotadas por cada sociedade é distinto. E é exatamente por possibilitar que grupos diferentes acumulem "adaptações culturais" para uma ampla faixa de ambientes que a cultura cumulativa evoluiu em nossa espécie. Por si só, contudo, a simples existência de variação entre os grupos não é uma condição suficiente para que a seleção de grupo se torne uma força evolutiva a ser contabilizada. É preciso que essa variação seja mantida ao longo do tempo.

Há dois mecanismos psicológicos que poderiam induzir a manutenção da variação cultural entre grupos humanos distintos: a punição moral e o viés conformista. Esses mecanismos são responsáveis pela manutenção da alta diversidade cultural humana, que é tão valorizada pela teoria social. A teoria da dupla herança, portanto, é capaz de explicar um elemento conceitual que é assumido como pressuposto nas ciências sociais: as diferenças culturais características da espécie humana.

A punição moral resulta de um dos mecanismos propostos pelos sociobiólogos para explicar a cooperação entre outros animais, o altruísmo recíproco. Esse mecanismo baseia-se na premissa de que um indivíduo que coopere com os altruístas e puna os oportunistas terá uma maior aptidão biológica, no longo prazo, do que indivíduos que tentassem, a todo instante, explorar os altruístas. ${ }^{6} \mathrm{~A}$ punição moral pode estabilizar uma determinada variante cultural, impedindo que outras se estabeleçam e possibilitando a variação cultural entre grupos distintos, promovendo a estabilização destas variantes em uma determinada população.

Outro mecanismo psicológico que favorece a manutenção da variação cultural entre grupos diferentes é o viés conformista. A seleção natural favoreceu, na linhagem hominídea, uma psicologia inata capaz de imitar as variantes culturais mais comuns de uma população, favorecendo a sua disseminação e a diminuição da frequência das mais raras. Com a imitação das variantes culturais mais comuns, a variação cultural pode ser mantida, porque mesmo os imigrantes aprendem as variantes culturais mais comuns no grupo e passam a comportar-se de acordo com o esperado pela comunidade (RICHERSON; BOYD, 2005, p. 203-204). Esse efeito é ainda maior se o viés conformista for aliado à punição moral, uma vez que os imigrantes passam a respeitar as variantes culturais comuns, já que o risco de sofrer punição torna mais custosa a adoção de variantes diferentes das comuns. Há cerca de 200.000 anos, a mente de nossos ancestrais já era dotada das pré-condições psicológicas (o viés 
conformista e a capacidade de punir moralmente) necessárias para a diferenciação cultural entre as várias sociedades humanas.

Com o surgimento de vários grupos sociais de hominídeos, é provável que tenha ocorrido competição pelos melhores recursos ambientais. Com efeito, as evidências antropológicas sugerem que as sociedades arcaicas que ainda existem hoje são bastante belicosas. As pesquisas do antropólogo Joseph Soltis, a partir de registros etnográficos realizados na Nova Guiné e na Venezuela, por exemplo, sugerem que o conflito entre grupos é bastante comum (SOLTIS; BOYD; RICHERSON, 1995, p. 477; IRONS, 2009). Essa constatação é relevante, no presente contexto, tendo em vista que um dos modos pelos quais os antropólogos inferem o comportamento das sociedades pré-históricas é pelo estudo das sociedades arcaicas contemporâneas. Assim, é razoável supor que as primeiras sociedades humanas também eram bastante belicosas, como as pesquisas antropológicas sugerem. Postulando a veracidade desse cenário, é plausível a conclusão de que as comunidades humanas pré-históricas competiam entre si pelos recursos ambientais a sua disposição.

Com isso, estão presentes todos os elementos para que a seleção natural atue sobre as próprias comunidades: há variação (cultural) entre grupos, herança (evolução cultural) em cada grupo e competição (conflitos intergrupais).

A capacidade para a imitação, o viés conformista e a punição moral viabilizaram a acumulação cultural e a diferenciação cultural das diversas comunidades pré-humanas. Favoreceu-se, portanto, a seleção de mentes capazes de lidar com variantes culturais cada vez mais sofisticadas em sociedades também cada vez maiores. Essas mentes, por sua vez, eram capazes de lidar com um nível complexidade cultural ainda maior. Esse processo provavelmente teve como consequência o surgimento de culturas cada vez mais complexas, que demandavam mentes ainda mais sofisticadas, iniciando-se um longo processo de coevolução entre os genes responsáveis pelo aprendizado cultural e a cultura. ${ }^{7}$ Culturas mais complexas exigem mentes mais aptas a lidar com variantes culturais, que, por sua vez, possibilitam o surgimento de culturas ainda mais sofisticadas.

Uma das consequências da seleção de grupo foi a evolução de uma psicologia inata capaz de se identificar com marcadores simbólicos que caracterizam um grupo social. ${ }^{8}$ A marcação simbólica é um elemento bastante relevante para compreender a evolução da cooperação humana. Os marcadores simbólicos sinalizam a pertença a uma comunidade moral que aplica as normas morais que fazem parte de sua cultura. O viés conformista facilita a aprendizagem dessas normas, que são imitadas e reforçadas pela comunidade por meio da punição. É provável que alguns dos elementos necessários para a evolução da psicologia que sustenta a marcação simbólica estejam relacionados também à evolução da linguagem (DUNBAR, 2002).

Todos esses aspectos presentes na evolução humana favoreceram a seleção de instintos específicos, que moldaram a estrutura da sociabilidade humana. Essa é a hipótese 
dos instintos sociais tribais, um elemento importantíssimo para compreender como evoluiu a "mente normativa". Progressivamente, os ancestrais humanos se organizaram em grupos cada vez maiores, cujos membros eram bastante cooperativos internamente e se identificavam por meio de marcadores simbólicos. Os membros dessas comunidades eram "altruístas" com outros membros do grupo, mas agressivos com relação a outras comunidades, o que levava frequentemente a conflitos intergrupais e ao surgimento de grupos cada vez maiores e culturalmente mais sofisticados. Grupos equipados com variações culturais que tornassem mais provável a vitória contra outros grupos - como melhores armas, estratégias de guerra ou instituições que assegurassem a cooperação interna -, seriam capazes de vencer conflitos com grupos menores e portadores de "adaptações culturais" relativamente inferiores. Essa corrida armamentista favoreceu a evolução social de comunidades cada vez maiores e mais cooperativas, internamente. As evidências arqueológicas citadas pelos autores sugerem que, há cerca de 100.000 anos, no Pleistoceno, a estrutura das sociedades humanas era parecida com a das tribos contemporâneas de caçadores coletores, como os !Kung San, que vivem no deserto do Kalahari, na Namíbia (RICHERSON; BOYD, 2005, p. 214).

Mas a estabilidade de grupos sociais compostos de um grande número de indivíduos só se tornou possível graças à evolução de novos instintos sociais (viés conformista, viés de seguir modelos, bem como instintos sociais como a vergonha e a empatia, e a propensão a punir moralmente), que resultaram das forças evolutivas descritas nas seções anteriores (RICHERSON; BOYD, 2005, p. 214-215). Esta é a hipótese dos instintos sociais tribais: a vida em grandes sociedades ao longo de milhares de gerações favoreceu a evolução genética de instintos e emoções que facilitam a sobrevivência em grupos culturais.

Esses instintos foram selecionados e agrupados com outros instintos que compartilhamos com outros animais. O cérebro humano, assim como o dos demais mamíferos, é composto de três seções principais: o cérebro primitivo, que herdamos de nossos ancestrais reptilianos; o cérebro médio (mesencéfalo) e outras áreas subcorticais, que se relacionam à integração sensorial; e o córtex, que é a camada mais externa e é mais específica dos mamíferos (DUNBAR, 2002, p. 61). Provavelmente, muitos dos sistemas cerebrais relacionados à cooperação humana também derivam dos sistemas que organizam a sociabilidade da vida nos outros animais. A maior parte da cooperação em animais não humanos pode ser explicada pela seleção de parentesco e pelo altruísmo recíproco, que dependem de instintos e emoções básicos. A seleção de parentesco, por exemplo, favorece a seleção de instintos que predisponham o animal a agir em defesa de interesses de animais geneticamente relacionados. O cuidado parental, por exemplo, pode ser explicado a partir desse mecanismo. No entanto, o altruísmo recíproco pode favorecer a seleção de instintos, emoções e estruturas mentais que tornem o animal capaz de monitorar, nas relações sociais, quem é 
digno de confiança. E esses instintos também estão presentes na mente humana, o que torna razoável a suposição de que mecanismos como a seleção de parentesco e o altruísmo recíproco explicam não apenas a cooperação entre outros animais, mas também grande parte da cooperação entre humanos.

A trajetória da evolução humana, contudo, levou ao surgimento de outros instintos (os instintos sociais tribais), que não são compartilhados entre a espécie humana e outras espécies animais. Segundo a proposta da teoria da dupla herança, esses instintos operam de maneira análoga ao modo pelo qual os humanos aprendem a linguagem. Segundo a tese da gramática gerativa, defendida por Noam Chomsky, as crianças são dotadas de mecanismos psicológicos que tornam possível o aprendizado rápido e acurado da linguagem que elas escutam a sua volta. Esses mecanismos funcionam a partir de princípios universais que limitam a faixa de interpretações possíveis que as crianças podem atribuir às sentenças que escutam. Mas esses princípios são suficientemente abstratos de modo a possibilitar o aprendizado de uma infinidade de linguagens: os princípios são universais, mas os parâmetros são fixados culturalmente e, portanto, são variáveis (CHOMSKY, 1997). Em outras palavras, temos um "instinto da linguagem" que, embora opere a partir de determinados princípios universais, é flexível o suficiente para possibilitar a diversidade de linguagens que podemos observar em todas as culturas. Richerson e Boyd propõem que esse instinto da linguagem teria coevoluído com as linguagens empregadas pelos vários grupos humanos do Pleistoceno e que um processo análogo de coevolução entre genes e cultura também deve ter ocorrido entre os instintos sociais tribais e as normas sociais transmitidas culturalmente (RICHERSON; BOYD, 2005, p. 216).

Uma psicologia propensa a se identificar com marcadores simbólicos, que possibilitam a interação seletiva dos membros da mesma comunidade, bem como a respeitar normas sociais (variantes culturais específicas que ditam o comportamento esperado e as punições aplicáveis), é essencial para a sustentação de sistemas cooperativos como os humanos. Essa rede simbólica de variantes culturais está na origem dos sistemas normativos humanos como o direito, a religião e a moral. É possível supor que esses sistemas estavam presentes, ainda que rudimentarmente, mesmo antes do surgimento inequívoco do homem anatomicamente moderno. Afinal, boa parte dos requisitos psicológicos necessários para a evolução da psicologia necessária para a sustentação da vida social humana nos últimos 100.000 anos depende de mecanismos típicos desses sistemas sociais, como a punição moral aliada a um sistema de normas morais.

As evidências indicam que os instintos sociais tribais seriam os seguintes: (i) altruísmo e empatia; (ii) tendência para praticar punição moralista e buscar recompensas; (iii) uma tendência à igualdade; e (iv) instintos que favorecem a identificação com marcadores simbólicos. Esse seria também o núcleo da mente normativa: uma mente capaz de raciocinar a partir de normas sociais e de aplicá-las a situações concretas. 
Esse processo não é necessariamente consciente: ao aplicar uma norma social ou ao reconhecer a justiça ou a injustiça de uma situação, muitas vezes sabemos qual é a decisão correta, mas não sabemos justificá-la; e uma explicação possível para isso, compatível com tudo o que se discutiu até aqui, sugere que essa decisão é instintiva. ${ }^{9}$ Em outras palavras, nossa mente operaria a partir de uma gramática moral universal, que estrutura nossa experiência moral e a forma pela qual formulamos juízos normativos.

A tese de que a psicologia humana é caracterizada por um viés para aplicar a punição moralista e pela adoção de uma psicologia igualitária é reforçada por evidências antropológicas. O antropólogo darwinista Christopher Boehm reuniu várias evidências etnográficas que sugerem a existência de um viés psicológico para a punição de quem não se conforma às normas de sua comunidade. Esta seria uma característica universal de sociedades contemporâneas de caçadores-coletores a existência de mecanismos de controle social cujo objetivo precípuo é assegurar o cumprimento das normas sociais e a punição de quem as transgride (BOEHM, 1999, p. 72-80).

De acordo com Boehm, esses mecanismos são fruto de uma psicologia que nos distingue fundamentalmente dos outros primatas - uma psicologia que valoriza a igualdade. E, segundo o antropólogo, esses mecanismos de controle social, nas sociedades arcaicas, objetivavam justamente a proteção contra qualquer um que viesse a subverter a relação de igualdade entre os indivíduos de uma tribo - de modo que as sociedades arcaicas são caracterizadas justamente pela igualdade entre todos os membros, que rejeitam qualquer tentativa de dominação hierárquica do poder por parte do chefe da tribo (BOEHM, 1999, p. 69). A hipótese formulada por Boehm parte do pressuposto de que nossos ancestrais tornaram-se igualitários em razão de fatores culturais - que, em contrapartida, favoreceram a seleção de uma psicologia igualitária. Essa psicologia igualitária é bastante diferente da presente em outros primatas, como os chimpanzés e gorilas, que são animais essencialmente hierárquicos. Mas isso não significa dizer que somos totalmente diferentes de outros primatas: Boehm sugere que o igualitarismo humano é baseado em uma psicologia hierárquica inversa. Em vez de as hierarquias humanas serem fundamentadas em uma pirâmide na qual o topo é menor do que a base e há uma cadeia de comando distribuída por toda a comunidade, a psicologia igualitária seria baseada em uma pirâmide invertida, em que é o líder quem deve obediência às normas comunitárias, e não o contrário, como seria esperado em uma hierarquia tradicional (BOEHM, 1999, p. 173-174).

Por fim, Boehm destaca ainda que os ancestrais humanos viviam em comunidades morais, construídas a partir de emoções ligadas a marcadores simbólicos. Segundo o antropólogo, uma comunidade moral é caracterizada pelo compartilhamento de marcadores comuns que tornam um indivíduo ligado emocionalmente ao grupo. Hinos, bandeiras, uniformes, línguas, entre tantos outros elementos, são marcadores que podem ser utilizados para identificar quem pertence e quem não pertence ao grupo - 
e, portanto, para identificar quem é digno de confiança ou não (RICHERSON; BOYD, 2005, p. 222; GIL-WHITE, 2001, p. 515).

A teoria da dupla herança possibilita formular hipóteses interessantes a respeito de questões fundamentais para a teoria moral e, particularmente, para a teoria do direito. Segundo essa teoria, a capacidade humana de formular juízos normativos é fruto de um longo processo de coevolução entre nossa bagagem genética e a cultura, que induziu a seleção natural de instintos sociais tribais que, por sua vez, possibilitaram a vida em sociedades cada vez maiores, caracterizadas por culturas cada vez mais complexas.

Todavia, a teoria da dupla herança possibilita ir além do que explicar como a mente normativa evoluiu e qual foi o papel de instituições normativas (como o direito, a moral e a religião) nesse processo evolutivo.

A seguir, serão exploradas algumas implicações desse marco teórico para a melhor compreensão de questões importantes para a teoria do direito.

\section{IMPLICAÇÕES DA TEORIA DA DUPLA HERANÇA PARA A TEORIA DO DIREITO:} O DEBATE ENTRE O JUSNATURALISMO E O JUSPOSITIVISMO

Um dos problemas mais controvertidos da filosofia jurídica diz respeito à justificação normativa das obrigações legais. Por que devemos respeitar as leis e as instituições? Por que as leis são válidas? O que torna obrigatório o direito? Existem limites ao poder das autoridades de criar direitos e deveres? A resposta a essas questões, clássicas na filosofia do direito, tradicionalmente deriva de teorias alinhadas a duas posições padrão: o jusnaturalismo e o positivismo jurídico. As teorias jusnaturalistas buscam responder àquelas questões a partir da ideia de que existem certos princípios normativos universais, cuja validade não deriva de normas socialmente estabelecidas, mas da própria natureza. Outra característica típica das teorias jusnaturalistas está na fundamentação da validade do direito positivo (o direito estabelecido por meio de convenções sociais). As leis impostas pelo Estado só são consideradas válidas se forem compatíveis com o direito natural, princípios universais e imutáveis da moralidade humana. Assim, o jusnaturalista considera que a obrigatoriedade e a validade do direito derivam de normas morais pré-sociais, derivadas de certo ideal de natureza (KELSEN, 2003, p. 71).

Embora não haja consenso entre as teorias jusnaturalistas - os antigos concebiam o direito natural como parte da physis, os medievos o concebiam como produto da vontade divina e os modernos, como o fruto da razão humana -, é possível admitir alguns traços comuns a todas as teorias. Segundo as teorias jusnaturalistas, em regra, o direito natural confere especial legitimidade ao direito positivo, cuja validade decorre justamente da observância dos preceitos do direito natural. Os jusnaturalistas admitem que o direito positivo varie culturalmente de sociedade para sociedade, desde que ele esteja em harmonia com os postulados do direito natural. 
No entanto, o positivismo jurídico não atribui qualquer papel essencial ao direito natural. Nessa concepção, as sociedades humanas são regidas fundamentalmente pelo direito positivo, isto é, pelo direito que deriva de uma convenção social. Segundo Hans Kelsen, um dos maiores expoentes da teoria positivista, não é possível derivar a validade de uma norma jurídica da natureza, ou do direito natural, uma vez que os valores acolhidos pelas diversas teorias morais são arbitrários, não sendo possível estabelecer premissas universalmente válidas sobre as quais o direito positivo poderia se fundamentar (KELSEN, 1998, p. 20). A validade das normas jurídicas somente pode ser estabelecida a partir de outras normas jurídicas válidas, o que impõe outra questão: se uma norma é válida porque pressupõe outra norma do ordenamento positivo, isso levaria a uma regressão ad infinitum. Para resolver esse problema, Kelsen propõe, como postulado lógico, a existência de uma norma fundamental que confere validade a todo um ordenamento jurídico e a ela mesma (KELSEN, 1998, p. 53).

Outro positivista, Herbert L. A. Hart, também concebia o direito como um conjunto de normas hierarquicamente constituído. Segundo Hart, o direito é um sistema de regras primárias e secundárias. ${ }^{10}$ Assim como a norma fundamental de Kelsen, a regra de reconhecimento é um pressuposto lógico das convenções sociais a respeito do que é o direito (HART, 2001, p. 114-115). Assim, o conceito de validade, fundamentado sobre a aceitação social das normas jurídicas, que se reflete na norma fundamental (Kelsen) ou na regra de reconhecimento (Hart), é um elemento crucial do modo pelo qual as teorias positivistas caracterizam o direito. Outro elemento bastante comum nas teorias positivistas é a ideia de sanção. Segundo Kelsen, o direito é uma ordem normativa coativa, que atribui sanções como consequência da prática de uma ação prevista em uma norma. Embora Kelsen entenda que o fato de a sanção compelir os membros de uma sociedade a cumprirem as leis seja relevante, para ele a essencialidade da ideia de sanção para o direito está no fato de que toda norma jurídica deva estabelecer uma sanção como consequência dos pressupostos estabelecidos por ela (KELSEN, 1998, p. 38).

As diferentes teorias do direito natural compartilham pelo menos dois traços. Em primeiro lugar, as teorias jusnaturalistas assumem que todos os seres humanos têm um senso moral, a capacidade cognitiva de reconhecer normas morais universalmente válidas, avaliar o que é certo e o que é errado e agir de acordo com essa avaliação. Além disso, as teorias jusnaturalistas também defendem a tese de que essas normas - o direito natural - fundamentam moralmente aquelas estabelecidas por meio de convenções sociais (o direito positivo). No entanto, as teorias juspositivistas defendem a irrelevância do direito natural, por considerarem que as teorias morais sobre as quais se sustenta o direito natural são diversas demais para que se estabeleça uma base consensual de fundamentação moral para o direito positivo. Segundo os teóricos do positivismo jurídico, a legitimidade do direito 
positivo deriva de sua aceitação social e de sua eficácia, que resulta da aplicação das sanções previstas normativamente. A positividade do direito, portanto, deriva do binômio legitimidade-sanção.

A teoria da dupla herança pode ser útil na compreensão do embate clássico entre os positivistas jurídicos e os jusnaturalistas e, principalmente, na elucidação dos termos desse debate. A contribuição mais evidente da teoria da dupla herança, nesse contexto, diz respeito às assertivas centrais dos jusnaturalistas, a saber: (1) os seres humanos possuem um senso moral que constituiria parte de sua racionalidade prática; e (2) existem normas morais universalmente válidas cognoscíveis por meio da razão.

A suposta existência de um senso moral é compatível com a teoria da dupla herança. A mente humana é composta de camadas sobrepostas de mecanismos relacionados à ação moral. Em primeiro lugar, estão os mecanismos relacionados ao altruísmo entre indivíduos aparentados, fruto da seleção de parentesco. Assim, é razoável a tese de que o cuidado com os filhos - que o próprio Santo Tomás de Aquino (2008, Questão n. 94, artigo $2^{\circ}$ ) reconhecia como um dos preceitos de direito natural - tem um importante componente genético. Além disso, entrelaçado a esses mecanismos, está um conjunto de mecanismos mentais selecionados com base no altruísmo recíproco - estruturas cognitivas que reconhecem relações de reciprocidade, situações de igualdade e desigualdade e que possibilitam identificar oportunistas, bem como emoções que possibilitam a punição dos trapaceiros e a reação contra situações consideradas injustas. Nessa perspectiva, o senso moral seria o produto de instintos e estruturas cognitivas capazes de identificar e cooperar com indivíduos aparentados, bem como de cooperar sempre que se divisar a possibilidade de, no futuro, obter ganhos recíprocos, identificando e punindo trapaceiros. Emoções como o amor pelos parentes (em especial, com aqueles que compartilhamos mais genes, como os filhos), ciúme, inveja e indignação contra as injustiças poderiam ser explicados por esses mecanismos.

Ao lado desses mecanismos, a teoria da dupla herança sugere a existência de outra estrutura cognitiva, baseada nos instintos sociais tribais. Entre esses instintos estariam a identificação com marcadores simbólicos próprios do grupo a que o indivíduo pertence, que levaria à empatia com membros de seu grupo e ao respeito pelas normas socialmente aceitas, bem como a predisposição a punir quem não as cumprisse - talvez uma "exaptação"11 dos mecanismos de punição associados ao altruísmo recíproco.

Esses instintos se entrelaçam em nossa psicologia social, constituindo o cerne do que Marc Hauser denomina de gramática moral universal. Segundo Hauser, nossa mente identifica instintivamente a diferença entre normas morais e convenções sociais. As normas morais, associadas aos princípios morais que constituem o cerne de nosso senso moral, geram vínculos emocionais intensos. A violação a uma norma moral atrai uma resposta emocional imediata e aguda. As convenções sociais, por sua 
vez, atraem uma resposta emocional mais branda, mas ainda assim significativa (HAUSER, 2006, p. 237-238). A distinção entre convenções sociais e normas morais também parece ajustada à descrição da mente normativa proposta pela teoria da dupla herança. A violação de uma norma moral ativa mecanismos mentais mais primitivos, associados aos princípios da gramática moral universal que evoluíram ao menos na linhagem dos primatas, muito antes de a evolução cultural ter se entrelaçado com a evolução biológica. Assim, é previsível que esses mecanismos disparem emoções muito mais intensas do que a violação de normas meramente convencionais, parametrizadas culturalmente e remetendo aos instintos sociais tribais, que evoluíram mais recentemente, nos últimos 200.000 anos.

Os instintos mencionados, assim como as estruturas cognitivas subjacentes, constituem o cerne daquilo que poderia ser chamado de direito natural em uma perspectiva biológica. Nesse sentido, é possível sustentar tanto a existência de um senso moral - que molda a forma por meio da qual a experiência normativa é construída - quanto a predisposição cognitiva à aceitação de determinadas normas, compatíveis com nossos instintos sociais. Adotando-se essa premissa, é razoável aceitar a universalidade de certos valores e preceitos morais, como o amor pelos pais, a aceitação da igualdade, a indignação contra quem viola normas socialmente aceitas e a reação a situações injustas. A psicologia moral inata incorpora, como produto das forças evolutivas, determinados valores sobre os quais as instituições sociais se fundamentam (embora esses valores possam ser rejeitados a partir de uma reflexão moral adequada). De certa maneira, portanto, a teoria da dupla herança aceita a premissa jusnaturalista de que as instituições sociais dependem da estrutura universal da cognição humana.

O fato de as instituições serem construídas sobre uma psicologia inata, que incorpora princípios em sua estrutura cognitiva, contudo, não impede que a dinâmica da evolução cultural tenha levado a sociedades culturalmente muito diversas, que adotam normas jurídicas bastante diferentes umas das outras. A evolução cultural propiciou o aparecimento de sociedades coesas, cujas variantes culturais entre as quais estão as normas jurídicas - implicassem uma maior ou menor aptidão cultural. O ponto a ser destacado é que, apesar da ampla variação existente nas sociedades, nem toda variante cultural pode se estabilizar, já que algumas variantes, por serem incompatíveis com a estrutura de nossa cognição, seriam muito difíceis de serem aprendidas e, portanto, dificilmente se estabilizariam ao longo de muitas gerações. Nesse sentido, as normas jurídicas precisam ser minimamente compatíveis com a estrutura de nossa cognição para se estabilizarem ao longo do tempo (RUBIN, 2002, p. 2).

Nesse ponto, fica claro o quanto as posições do positivista jurídico e do jusnaturalista se complementam quando examinadas do ponto de vista da teoria da dupla herança. O jusnaturalista está parcialmente certo ao afirmar que existem princípios 
normativos sobre os quais a estrutura do direito está fundamentada. O direito natural inscrito em nossa mente, que determina a estrutura da experiência moral possível, é baseado em certos princípios universais. Mas, ao contrário do que o jusnaturalista poderia esperar, esses princípios acomodam uma grande diversidade de parâmetros culturalmente determinados - e não apenas os valores morais considerados corretos pelos filósofos jusnaturalistas. É possível descobrir, por meio de experimentos psicológicos, os princípios inatos da gramática universal moral, mas, dada a sua abrangência e indeterminação, não seria correto invocá-la para avaliar, normativamente, a validade de um determinado conjunto de normas jurídicas, como propunham os teóricos jusnaturalistas. Na verdade, todos os sistemas jurídicos que já existiram são fundamentados sobre esses princípios, que são inerentes a nossa cognição normativa.

Isso não significa, contudo, que a posição do filósofo juspositivista seja indefensável. Segundo o positivista jurídico, tentar estabelecer uma moralidade universal que determine o conteúdo normativo das normas jurídicas é um empreendimento impossível e inútil. Ele poderia até invocar a história humana em sua defesa, argumentando que as sociedades humanas acolheram os mais diversos valores morais, não sendo possível defender que o direito positivo somente seja válido se respeitar uma determinada concepção moral. Como defender, por exemplo, que nossa psicologia moral inata é igualitária, se a escravidão foi uma realidade desde a Antiguidade até há pouco menos de duzentos anos, e se as desigualdades sociais ainda são uma marca característica das sociedades contemporâneas?

Para responder ao desafio posto pelo juspositivista, é preciso recorrer ao modo pelo qual a evolução cultural se entrelaça à dinâmica da evolução biológica. Como salientado, a evolução cultural é sustentada pelos instintos sociais tribais, que são constituídos por determinadas predisposições inatas, como o viés conformista e o viés a seguir modelos, além de emoções particulares. Essa psicologia social inata, que fixa os princípios universais da gramática moral universal em parâmetros determinados culturalmente em uma comunidade particular, torna possível a vida em pequenos grupos, compostos de aproximadamente 150 indivíduos (DUNBAR, 2002).

A atuação da seleção natural no nível de grupo, contudo, induziu a evolução de sociedades compostas de um número maior de indivíduos do que o sustentado por aquela psicologia. Sociedades maiores são mais aptas a vencer confrontos militares do que sociedades menores, além de possibilitar uma melhor divisão do trabalho, com consequentes ganhos econômicos (RICHERSON; BOYD, 2005, p. 230).

Sociedades muito grandes, contudo, não são estáveis. Para contornar esse problema, foi necessária uma adaptação estritamente cultural - a segmentação das sociedades em grupos menores, compostos de um número de membros compatível com o possibilitado pelos instintos sociais tribais. ${ }^{12}$ Todavia, sociedades puramente segmentadas também não são estáveis, já que carecem de um poder diretivo centralizado, 
que possa ordenar as forças econômicas e sociais em prol de toda a comunidade. Para contornar esse problema, foi necessária uma segunda adaptação cultural, construída de forma a adaptar nossos instintos sociais à necessidade de organização centralizada pressuposta na hierarquização dos grupos sociais (RICHERSON; BOYD, 2005, p. 230).

A hierarquização social, contudo, é construída com base em grupos menores, compatíveis com nossa psicologia social. A hierarquia se estabelece entre grupos, no interior dos quais a estrutura social é igualitária, reproduzindo as condições de vida das tribos de caçadores coletores do Pleistoceno. Possivelmente, a desigualdade social e econômica, embora incompatível com a nossa psicologia social inata, surgiu como produto da evolução cultural, que somente tornou possível sociedades gigantescas como as sociedades contemporâneas a partir da cisão dos grupos sociais em grupos menores hierarquicamente organizados, no interior dos quais há certo igualitarismo típico das sociedades pré-históricas, compatível com nossa psicologia. A hierarquização, aliada à marcação simbólica - que favorece a identificação com membros do mesmo grupo e a cooperação entre eles -, induziria certo preconceito entre os membros dos mais diversos grupos sociais. Nessa estrutura, seria razoável esperar que os grupos "superiores", que administrassem os recursos sociais, tratassem com desdém os membros de grupos hierarquicamente inferiores. Assim, mesmo que indiretamente, a evolução cultural pode levar à construção de sociedades profundamente desiguais construídas sobre a estrutura de uma mente igualitária.

De certa maneira, as posições jusnaturalista e juspositivista são parcialmente endossadas por uma abordagem a partir da teoria da dupla herança. Ao contrário do que alega o positivista, mesmo as mais diferentes culturas estão assentadas sobre uma estrutura psicológica inata, carregada de valores universais que moldam nossa experiência social. Embora a diversidade de valores seja um produto da evolução cultural, ela se assenta em uma psicologia moral inata que, ao menos, constrange o espectro possível de valores. Mas o jusnaturalista também não adota uma posição de todo correta: afinal, não há um único conjunto de valores compatível com nossa psicologia social inata. O espectro cultural permitido por nossa psicologia admite uma ampla margem de valores morais. Seria arbitrário dizer que apenas um subconjunto dos valores humanos é compatível com a narrativa evolutiva proposta pela teoria da dupla herança.

A posição jusnaturalista - segundo a qual o direito respeita princípios universais e inatos - pode ser acolhida, desde que se compreenda essa posição como uma constatação fática, e não como uma avaliação normativa. Os princípios de moralidade constituídos por nossa psicologia social inata, de fato, estruturam grande parte das normas sociais possíveis. É difícil conceber sociedades em que o homicídio injustificado e indiscriminado de concidadãos seja permitido, nas quais seja determinado que as crianças sejam indiscriminadamente assassinadas pelos pais, ou, ainda, onde nenhuma 
transação econômica seja realizada com base em um princípio de troca recíproca. As normas jurídicas dessas sociedades seriam irremediavelmente contrárias à maneira pela qual nossa mente raciocina normativamente e, por isso, tais sociedades dificilmente poderiam se estabilizar por longos períodos de tempo. Mas esta é uma constatação fática, e não normativa. As posições jusnaturalistas clássicas, contudo, pretendem ir além disso: elas não sustentam apenas que o direito seja assentado sobre os princípios inscritos em nossa mente, mas que o direito deve ser assentado sobre tais princípios, porque eles são corretos. É difícil que uma posição normativamente forte como essa poderia ser defendida a partir das premissas evolutivas apresentadas.

Além disso, a posição jusnaturalista clássica postula uma hierarquização entre princípios inatos e universais de moralidade, de um lado, e o direito positivo, de outro. O entrelaçamento evolutivo entre genética e cultura proposto pela teoria da dupla herança dificilmente autorizaria essa conclusão. Os princípios da gramática moral universal podem ser ajustados a uma ampla diversidade de valores sociais parametrizados culturalmente, de forma que os fatores culturais não podem ser considerados meramente subordinados aos fatores genéticos: nossa experiência normativa é moldada justamente pela confluência de ambos os fatores. Além disso, nunca é demais lembrar que a cultura é uma causa última da própria psicologia inata, de modo que os próprios princípios da gramática moral universal são fruto, em última instância, do papel da cultura na história evolutiva humana! Dessa forma, não há como postular a primazia do inato sobre o cultural - de certa maneira, o direito positivo e o direito natural seriam complementares, os dois lados da ação normativa.

O positivismo jurídico, portanto, está parcialmente correto ao considerar fracassada a tentativa jusnaturalista de buscar validar o direito positivo de uma sociedade verificando a sua compatibilidade com determinados valores inerentes à natureza humana ou descobertos graças à faculdade natural da razão. O equívoco do juspositivismo está na desconsideração de que o conteúdo do direito positivo possa ser parcialmente determinado pela conjunção de valores culturais que compuseram um nicho no qual evoluiu nossa psicologia social inata. Esses valores, obviamente, não validam o direito positivo - afinal, a validade é um conceito normativo, e não fático. Estabelecida uma norma de direito positivo que não se harmonize com os postulados de nossa psicologia social, ela não deixaria de ser válida por essa razão. Mas uma lei completamente incompatível com os pressupostos normativos de nossa psicologia social dificilmente seria eficaz - e a ineficácia completa de uma norma, como afirma Kelsen, levaria a sua invalidade.

No entanto, a teoria da dupla herança também fornece elementos importantes para justificar as teorias juspositivistas, que pressupõem como um dos fundamentos da validade do direito positivo a sua aceitação convencional por parte dos membros de uma determinada comunidade. Esse pressuposto é inerente às ideias da norma fundamental (Kelsen) e da norma de reconhecimento (Hart), cuja função é estruturalmente 
a mesma: instituir um critério de reconhecimento a respeito do que é e do que não é direito. Trata-se, em última instância, da afirmação da aceitação social como um critério de legitimação do direito, que pode, nessa medida, impor sanções.

A teoria da dupla herança corroboraria esse aspecto da teoria juspositivista. A cooperação em larga escala observada nas sociedades humanas somente é possível se os aproveitadores e oportunistas forem monitorados e punidos por toda a comunidade, que se responsabiliza por exigir a sua observância, além de exigir que os outros membros da comunidade também punam os transgressores, para evitar o oportunismo de segundo grau. O reconhecimento de que as normas sociais são compartilhadas por toda a comunidade e de que seu descumprimento deve implicar uma sanção, são característicos da definição de direito proposta pelo positivismo jurídico. A aplicação de sanções (punição moral) e a tendência de imitar o comportamento adotado pela maioria do grupo (viés conformista) e de cooperar com aqueles que compartilham os marcadores simbólicos são justamente os elementos invocados pelos juspositivistas para descrever o modus operandi do direito. Nesse esquema conceitual, o viés conformista propicia justamente as condições psicológicas para que os indivíduos consigam identificar a norma fundamental (ou a regra de reconhecimento) vigente. Ao imitar o comportamento da maioria, cada indivíduo aprende o que vale e o que não é válido como direito em sua própria comunidade. Também não surpreende que a ideia de sanção seja um conceito bastante presente nas teorias jurídicas, já que a psicologia social humana é inatamente programada para punir os transgressores com base nas normas consensualmente aceitas pelo grupo.

A teoria da dupla herança, assim, permite a dissolução da dicotomia que separa as abordagens jusnaturalista e juspositivista, sugerindo um terceiro caminho, no qual se reconhece a utilidade das categorias construídas pelas duas vertentes na compreensão do direito e sua estruturação, de uma maneira compatível com nosso conhecimento a respeito de nossa psicologia evoluída. Unidas, cultura e biologia tornam possível conceber uma teoria do direito que reconheça as naturezas cultural e biológica do Homo sapiens, e ajude a compreender melhor problemas clássicos da teoria jurídica.

: ARTIGO APROVADO (15/05/2013) : RECEBIDO EM 10/02/2012 


\section{NOTAS}

1 E, de fato, há evidências que parecem dar suporte à tese de que o comportamento normativo pode ser explicado sem o recurso à cultura. As pesquisas do etólogo e primatólogo holandês Frans de Waal, por exemplo, sugerem que os chimpanzés têm comportamentos especificamente voltados para a resolução de conflitos. Depois de um confronto entre dois chimpanzés, por exemplo, não é incomum que o vencedor da disputa se reconcilie com o perdedor, passando algum tempo catando seus parasitas e sujeiras, em um processo conhecido como catação (grooming), que é bastante custoso em termos biológicos, pois o relaxamento exigido pela catação expõe os chimpanzés a predadores ou ao ataque de chimpanzés adversários, além de demandar tempo considerável que poderia ser utilizado em outras atividades, como a busca por alimentos ou por parceiros sexuais. Outro comportamento que de Waal registra é a intervenção de chimpanzés de status hierárquico superior em conflitos envolvendo chimpanzés de status inferior, evitando que as disputas internas sejam danosas a longo prazo para o grupo (DE WAAL, 2000, p. 586-590).

2 Os termos "comunidade" e "sociedade" têm significados bastante específicos nas ciências sociais. Todavia, para os propósitos do texto, os termos serão tratados como sinônimos, para evitar uma repetição extensa destes vocábulos ao longo do texto.

3 Indivíduos capazes de viver em um mundo cultural podem resolver os problemas evolutivos enfrentados por nossos ancestrais de uma maneira ímpar (e inédita) no reino animal. Isso não significa dizer que a cultura seja algo inexistente em outros animais, já que há evidências de que primatas não humanos, como chimpanzés e algumas espécies de macacos, têm "cultura", em algum sentido do termo (MARTíNEZ-CONTRERAS, 2011), ou que mesmo golfinhos e aves também têm cultura (BLACKMORE, 1999, p. 50). Todavia, mesmo quando comparada aos grandes símios (chimpanzés, gorilas e orangotangos), a capacidade humana para viver em um mundo cultural é nitidamente mais sofisticada, em razão de a espécie humana ser a única capaz de aprender com base na imitação fidedigna do comportamento de outros indivíduos (RICHERSON; BOYD, 2005, p. 109; CHENEY; SEYFARTH, 2007, p. 184-190). Outras espécies seriam incapazes de imitar, apesar de poderem aprender comportamentos com base em outros mecanismos de aprendizado.

4 A transmissão enviesada compreende três vieses distintos: o viés de conteúdo (ou direto), o viés dependente da frequência e o viés de seguir modelos. No viés de conteúdo, um indivíduo assimila uma variante cultural em decorrência de seu conteúdo, por ser mais compatível com a sua estrutura cognitiva. O viés dependente da frequência, por sua vez, favorece o aprendizado da variante cultural com base na frequência com que ela aparece na população. Por fim, o viés de seguir modelos se refere à imitação preferencial das variantes culturais associadas aos indivíduos de sucesso ou de prestígio na população.

5 É importante mencionar que, ainda hoje, há um acalorado debate em torno da seleção de grupo. Recentemente, o biólogo Edward O. Wilson publicou o livro The social conquest of earth (2012), em que sustenta a relevância da seleção de grupo em processos evolutivos. A publicação dessa obra foi de particular relevância porque marcou uma mudança de posição de Wilson, que tradicionalmente defendera a posição padrão da sociobiologia, segundo a qual a seleção natural atua no nível do gene, e não de grupos. Steven Pinker, Richard Dawkins e outros, reagiram à manifestação de Wilson, em um debate que ainda perdura (PINKER, 2012).

6 Os fundamentos psicológicos da punição moral não são especificamente humanos. Há evidência de que outros primatas, como os chimpanzés, avaliam constantemente a reputação dos membros de seu grupo e punem os que não respeitam a hierarquia estabelecida (BOEHM, 1999, p. 23-30). Como os hominídeos compartilham um ancestral comum com os chimpanzés, é uma suposição plausível a de que a capacidade psicológica de monitorar e punir indivíduos oportunistas - e, portanto, de raciocinar reciprocamente - já estivesse presente na psicologia dos primeiros hominídeos (BOEHM, 1999, p. 149-150). É importante registrar, ainda, que está em debate na comunidade científica se outras espécies são efetivamente capazes de agir como exigido altruísmo recíproco. Alguns primatólogos, como Frans de Waal (2009) e Craig Stanford (2002, p. 114), sustentam que os chimpanzés são capazes de atuar conforme previsto pela teoria do altruísmo recíproco, mas também há quem defenda, como Riedl e Tomasello, entre outros (2012), não haver evidências suficientes para autorizar esta conclusão.

7 É importante notar que a coevolução entre genes e cultura não é um fenômeno raro, como poderia parecer à primeira vista. A literatura registra vários exemplos dessa interação. O primeiro exemplo deriva da hipótese formulada por alguns paleoantropólogos para explicar porque os homens modernos são menos robustos que seus ancestrais. Segundo eles, isso ocorreu em razão do uso de armas de longo alcance (como o arco e flecha). Antes da 
existência dessas armas, os genótipos mais robustos eram favorecidos pela seleção natural porque os embates se davam a curta distância; depois de sua invenção, tornou-se possível a caça à longa distância, exigindo menos vigor físico. Outro exemplo é o da evolução da capacidade de digerir lactose. Os europeus, asiáticos e os povos da região nordeste da África por muito tempo consumiram leite, favorecendo a seleção dos indivíduos capazes de digerir a lactose. O consumo de leite, contudo, era raro na América, nas ilhas do Pacífico e em boa parte da África, povos em que a intolerância à lactose é mais comum (RICHERSON; BOYD, 2005, p. 192-193).

8 Como exemplos desses marcadores, poderíamos mencionar elementos simbólicos como vestimentas (como o uso, comum entre os romanos, de cores distintas para caracterizar o pertencimento a um estrato social específico), adereços decorativos, dialetos específicos, entre outros, que são utilizados como marca distintiva do pertencimento a determinado grupo.

9 O psicólogo Lewis Petrinovich e o filósofo do direito John Mikhail, por exemplo, projetaram uma série de experiências baseadas em dilemas morais (os chamados trolley problems) nas quais se mostrou que, muitas vezes, os indivíduos oferecem respostas para o dilema ético envolvido, mas não sabem como justificá-las (HAUSER, 2006, p. 122-124; MIKHAIL, 2011).

10 Regras primárias são aquelas que impõem deveres, proibições ou estabelecem sanções. Regras secundárias, por sua vez, são divididas entre regras de adjudicação (conferem poder a certos indivíduos para decidir se uma regra primária foi violada), regras de mudança (estabelecem os modos pelos quais as regras primárias são introduzidas, alteradas ou eliminadas do sistema) e a regra de reconhecimento, que é uma metarregra subjacente a qualquer sistema jurídico, que define os critérios por meio dos quais uma norma pode ser afirmada como pertencente ou não ao direito de uma comunidade particular (HART, 2001, p. 102-105).

11 O termo "exaptação" foi proposto por Stephen Jay Gould e Elisabeth S. Vrba (1982) para definir uma característica que desempenha uma função, mas que não evoluiu por processos de seleção natural para aquele uso específico. Um exemplo seria o das penas das aves, que originalmente foram selecionadas em razão de serem bons isolantes térmicos. Posteriormente, as penas foram "exaptadas” para outra função - facilitar o voo.

12 É importante destacar que a sociologia também aponta para a segmentação das sociedades arcaicas em grupos menores, como destaca o sociólogo Niklas Luhmann (1983, p. 204-205).

\section{REFERÊNCIAS BIBLIOGRÁFICAS}

ABRANTES, Paulo César Coelho; ALMEIDA, Fábio Portela Lopes de. "Evolução humana: a teoria da dupla herança”. In: ABRANTES, Paulo César Coelho (Org.). Filosofia da biologia. Porto Alegre: Artmed, p. 261-295, 2011. BLACKMORE, Susan. The meme machine. Nova Iorque: Oxford University Press, 1999.

BOEHM, Christopher. Hierarchy in the forest: the evolution of egalitarian behavior. Cambridge (MA): Harvard University Press, 1999.

. "Impact of the human egalitarian syndrome on darwinian selection mechanics". The american naturalist, v. 150 , p. 100-121, 1997.

BOYD, Robert; RICHERSON, Peter J. The origin and evolution of cultures. Nova Iorque: Oxford University Press, 2005.

CAVALLI-SFORZA, Luigi L. "Cultural evolution”. American zoologist, v. 26, n. 3, p. 845-855, 1986.

CHENEY, Dorothy; SEYFARTH, Robert. Baboon Metaphysics - the evolution of a social mind. Chicago: The University of Chicago Press, 2007.

CHOMSKY, Noam. "Novos horizontes no estudo da linguagem". Delta: documentação de estudos em linguística teórica e aplicada, v. 13, p. 51-74, 1997.

DAMATTA, Roberto., Relativizando: uma introdução à antropologia social. Rio de Janeiro: Rocco, 1993.

DAWKINS, Richard. O gene egoísta. Tradução Geraldo H. M. Florsheim. Belo Horizonte, Itatiaia, 2001.

DE WAAL, Frans B. M. "Primates - a natural heritage of conflict resolution". Science, v. 289, p. 586-590, 2000.

DENNETT, Daniel. A perigosa ideia de Darwin: a evolução e os significados da vida. Rio de Janeiro: Rocco, 1998.

DUNBAR, Robin. Grooming, gossip, and the evolution of language. Cambridge (MA): Harvard University Press, 2002. 
DURKHEIM, Émile. As regras do método sociológico. Tradução Pietro Nassetti. São Paulo: Martin Claret, 2006. GOULD, Stephen Jay; VRBA, Elisabeth S. "Exaptation - a missing term in the science of form". Paleobiology, v. 8 , n. 1. p. $4-15,1982$.

GIL-WHITE, Francisco J. “Are ethnic groups biological 'species' to the human brain? Essencialism in our cognition of some social categories”. Current anthropology, v. 42(4). p. 515-554, 2001.

HAAG, Carlos. "O elo perdido tropical”. Revista pesquisa. Edição impressa n. 159, 2009. Disponível em: $<$ http://revistapesquisa.fapesp.br/index.php?art=3864\&bd=1\&pg=1\&lg=>. Acesso em: $29 \mathrm{mar} .2010$. HART, Herbert L. A. O conceito de direito. Tradução A. Ribeiro Mendes. Lisboa: Fundação Calouste Gulbenkian, 2001.

HAUSER, Marc D. Moral minds: how nature designed our universal sense of right and wrong. Nova Iorque: HarperCollins, 2006.

IRONS, William. "Genes and cultures - Boyd and Richerson: the intertwined roles of genes and culture in human evolution”. Zygon, v. 4, n. 2, p. 347-354, 2009.

KELSEN, Hans. Teoria Pura do Direito. Tradução João Baptista Machado. São Paulo: Martins Fontes, 1998. O problema da justiça. Tradução João Baptista Machado. São Paulo: Martins Fontes, 2003.

LALAND, Kevin N.; BROWN, Gillian. Sense and nonsense: evolutionary perspectives on human behavior. Nova Iorque: Oxford University Press, 2002.

LUHMAnN, Niklas. Sociologia do Direito I. Tradução Gustavo Bayer. Rio de Janeiro: Edições Tempo Brasileiro, 1983.

MARTÍNEZ-CONTRERAS, Jorge. “O modelo primatológico de cultura”. In: ABRANTES, Paulo César Coelho (Org.). Filosofia da biologia. Porto Alegre: Artmed, p. 224-240, 2011.

MIKHAIL, John. Elements of moral cognition: Rawls' linguistic analogy and the cognitive science of moral and legal judgment. Nova Iorque: Cambridge University Press, 2011.

PINKER, Steven. Tábula rasa - a negação contemporânea da natureza humana. Tradução Laura Teixeira Motta. São Paulo: Companhia das Letras, 2004.

"The false allure of group selection". Edge, 2012. Disponível em:

<http://edge.org/conversation/the-false-allure-of-group-selection>. Acesso em: 8 nov. 2012.

RICHERSON, Peter J.; BOYD, Robert. Not by genes alone: how culture transformed human evolution. Chicago: The University of Chicago Press, 2005.

RIEDL, Katrin et al. "No third-party punishment in chimpanzees". Proceedings of the National Academy of Sciences of The United States of America, v. 109, n. 37, p. 14824-14829, 2012.

RUBIN, Paul H. Darwinian politics: the evolutionary origin of freedom. New Brunswick (NJ): Rutgers University Press, 2002.

SANTO TOMÁS DE AQUINO. Summa Theologica. Kindle edition. MobileReference, 2008.

SOBER, Elliott; WILSON, David Sloan. Unto others - the evolution and psychology of unselfish behavior. Cambridge (MA): Harvard University Press, 1998.

SOLTIS, Joseph; BOYD, Robert; RICHERSON, Peter. “Can group-functional behaviors evolve by cultural group selection?”. Current Anthropology, v. 36, n. 3, p. 473-494, 1995.

STANFORD, Craig. “The ape's gift: meat-eating, meat-sharing, and human evolution”. WAAL, Franz de (Org.). Tree of origin: what primate behavior can tell us about human social evolution. Cambridge (MA): Harvard University Press, 2002.

WAAL, Frans de. Our inner ape. Nova Iorque: Penguin, 2005.

WILSON, Edward O. The social conquest of Earth. Nova Iorque: Liveright, 2012.

\section{Fábio Portela Lopes de Almeida}

Faculdade de Direito da UnB Campus Un. Darcy RIbeiro - 70774-010 Brasília - DF - Brasil fabio.portelalagmail.com
Mestre em Direito, Estado e Constituição PELA FACULdAdE DE DiREITO dA ÚnB

Mestre em Linguagem, Lógica e Filosofia da Mente PElo Departamento de Filosofia da UnB

Doutorando em Direito PELA FACULdADE DE DiREITO DA UnB

Visiting RESEARCHER PELA HARVARd LAW SchoOL 